\title{
Prevalence and Severity of Apple Scab in Uttarakhand Hills
}

\author{
R.K. Prasad ${ }^{1 *}$, K.P. Singh ${ }^{2}$, R.K. Gupta ${ }^{3}$ and J. Kumar ${ }^{2}$ \\ ${ }^{1}$ Depatment of Plant Pathology, College of Forestry, Ranichauri Tehri Garhwal, 249199 \\ Uttarakhand, India \\ ${ }^{2}$ Department of Plant Pathology, GBPUA\&T, Pantnagar U.S Nagar, Uttarakhand, India \\ ${ }^{3}$ Department of Botany, BHU, Varanasi, U.P., India \\ *Corresponding author
}

\begin{tabular}{|l|}
\hline Ke y w o r d s \\
Severity of Apple \\
Scab, \\
Uttarakhand Hills, \\
Scab incidence
\end{tabular}

\section{A B S T R A C T}

The prevalence of favorable weather conditions during the month of April to June. Disease incidence increased of scab was more in Auli and Gangotri valley then Purola- Naugaon, Tuni, KotiKanasar and Gwaldam of Garhwal hills. The study area included seven districts of Garhwal division and six district of Kumaon division. Scab was wide spread appearance in all the areas surveyed and incidence varied from 0 to 100 percent in tree. In Garhwal hills, the disease showed an increasing trend in all the apple areas, most of the areas District Dehradun (26\%), Uttarkashi $(41 \% \%)$, Chamoli $(21 \%)$ and Tehri (4\%) had scab. In district Uttarkashi, the disease was found to be more prevalent and widespread, in all the villages surveyed, cent percent orchard was found infected, the highest percent infected trees being in Harsil, Dharali, Jhalla, Mukhuwa, Jochira, Cholmi Bagori, Purali, Jashpur and Shukhi. In Puraola-Naugaon (Distt Uttarkashi), Chakrata (Distt Dehradun) and Gwaldam (Distt Chamoli) fruit belt, the incidence of scab was low and it was 1 to 13 percent on leaves and 0 to 6 percent on fruits. In Purola fruit belt, the disease was rather widespread than Chakrata fruit belt. The highest percent infected orchards being in Harsil and Auli, Joshimath. The disease was most severe in leaves and fruits in both the place. The incidence of scab ranged between 05 to 65 per cent on foliage and 5 to 35 per cent on fruits and intensity ranged between 0.01 to 0.30 percent in leaves an on fruits was observed during 2004 to 2006. Most of the orchards at Harsil recorded as high incidence as 85 per cent fruit scab. Chakrata fruit belt, disease could not be seen in Chakrata, Rawna and Patti areas while in others 20 to 60 percent orchards were affected by scab. At one of the other hot spot, Tuni and Koti-Kanasar (Distt Dehradun) of Chakrata fruit belt, spring infection was less, however, secondary scab appeared in severe form during summer and the rainy season and continued until September first fortnight. In Kumaon hills, the scab incidence was negligible.

\section{Introduction}

Weather is a most important factor in the development of apple scab, which is particularly severe in areas of high rainfall and relative humidity. Appraisal of losses due to scab is very important because it helps the government to decided how much to invest in research and extension programmes and the priorities to be fixed. Disease assessment is probably the most important aspect in any crop loss programme because it is the process that generates all the data that quantity progress of the disease. An acceptable disease assessment method / key is very essential on an orchard basis and must be satisfied during 
the testing stage prior to using the method for experimental or survey work. Yield, injury, damage and loss have defined by Zadoks (1987), in which yield is the measurable produce of economic value from a crop, injury in any visible and measurable symptoms caused by a harmful organism, damage is any reduction in quantity and / or quality of yield, and loss is the reduction in financial returns per unit area due to harmful organism. The expression of an infection as a discrete, easily recognized scabbed lesion allow apple scab disease to be identified and quantified with little difficulty, but some problems in assessing this disease do occur i.e. pin-point scab and light green non-sporulating lesions (Mac Hardy (1996). An autumn assessment of foliar scab is best with problems, scab lesions may be obscured by the surface growth of other fungi and by colour changes associated with leaf senescence. According to Nutter et al., (1999) incidence severity, prevalence, intensity and frequency, as used to express measurements of plant disease. With respect to scab, incidence has been expressed as the proportion or percentage of leaves, fruit, or shoots with scab lesions, or even of trees with scab lesions in an orchard. Disease severity (disease intensity) has been expressed as the average number of lesions per leaf (e. g. 0.2 lesion per leaf), average lesions per unit areas of leaf (e.g. 8 lesions per $\mathrm{m}^{2}$ leaf surface), and average lesions per infected leaf (e.g. 3.4 lesions per infected leaf), and the percentage or proportion of the leaf surface areas expressing symptoms (e. g. $20 \%$ or 0.02 leaf area areas scabbed). These expressions are used in plotting disease progress, in quantifying a scab epidemic, in disease simulation, in making scab management decision, and in determinations of physiological damage to the host caused by scab (Mac Hardy, 1996).

Losses from apple scab over a period of years are greater than from any other disease of apple. During field survey for proper assessment of scab on leaves and fruit, a uniform scab assessment is necessary. Tehon and stout (1930) from Illinois were the first to give a diagrammatic scale for scab assessment on apple leaves and fruits, representing ranges from 1-50 percent, Kearns et al., (1945) made the assessment of leaf samples with standard diagrams. These methods though well adopted for research purposes but were found time consuming in general survey year 1941 by the disease measurement committee set up by the B M S (Moore, 1943). Moore was apparently the first person to estimate scab by the category methods in the field. A better and rapid key for assessment of scab on leaves was given by Croxall et al., (1952). He also provide a visual and rapid key for assessing the intensity of scab development on the fruit during the growing seasons, where scab intensity ranged from 0.01 to 75 percent with a infection categories.

Apple scab is one of the difficult diseases to assess in the field. Incidence of scab may vary from tree to tree depend upon density of plantation, vigor, variety and age of the plant. The degree of infection may vary from plant to plant and the amount of scab on fruit may not always be closely related to that on leaves. Present studies where undertaken with an objective to evolve loss assessment and rapid methods of recording incidence and severity of scab in mixed $m$ cultivar orchards and identify cultivars resistant to scab.

\section{Materials and Methods}

Extensive survey of sub-mountain and low hills, sub-tropical and mid hill, sub-humid and parts of high hill temperate dry areas of different districts of Uttarakhand was undertaken during August 2004 and 2005. In each place ten to twelve orchards were included in the survey. At the fruit development stage, 10 trees were selected 
systematically in each orchard and ten vegetative shoots and 30 fruits were chosen at random on each selected trees, three on each side of the alley way. Incidence of disease on each tree in a locality was calculated as per the method given by Croxall et al., (1952). He developed $a$ "visual method" that utilized a key (Table 1) in which 0.01, 0.05, 0.25, 0.5, $1.0,5.0,10.0,25.0$, and 50 per cent of the leaf area covered with scab was estimated from the patterns of scab observed on a sampling unit. Croxall et al., (1952 b) also provided a visual and rapid key for assessing the intensity of scab development on the fruits during growing season, where scab intensity ranged from 0.01 to 75 percent with 9 infection categories (Table 2).

Eight promising cultivars were observed during 2004 to 2006 against the scab at farmers field, Dharali and Jochira, Harsil. Data were collected from two locations of Harsil an orchard (Dharali) located at road side, containing 8 to 10 year old cultivars and the other orchard (Jochira) located at high altitude (2585 $\mathrm{m}$ asl.) of the Gangotri fruit belt, containing 6 to 8 year old cultivars. Scab evaluations were made in different phenological stage of tree in each year by collecting 10 vegetative terminals which were selected and tagged on each tree. Selected shoots were equally spaced around the periphery of each tree. During assessment, the number of visibly diseased leaves and fruit were observed, and the total number of leaves and fruits were recorded. From these data, the proportion of infected leaves / fruits for each rating was calculated by using the method of Croxall et al., (1952 and 1953) while the severity was seen by taking into consideration the total area covered by scab on the vegetative terminal shoot and fruit. Severity was visually recorded on a 0 to 4 scale. The number of fruit were being assessed was to classify groups of apples, rather than individual apples, using the methods of Plotter and Kremer (1962) and Tomerlin and Jones (1983). Rating scale were using following method to assess the fruit scab.

Percent fruit infected (scabbed) was computed using the following formula

$\mathrm{P}=\frac{\mathrm{Sum} \text { of }(\mathrm{n} \times \mathrm{v})}{\mathrm{Z} \times \mathrm{N}}$

Where

$\mathrm{P}=$ Percent infection or percent damage

$\mathrm{N}=$ number of plant parts in each category

$\mathrm{V}=$ numerical value of categories

$\mathrm{Z}=$ numerical value of highest category

$\mathrm{N}=$ Total number of plant parts.

\section{Cultivars reaction}

Twelve promising cultivars were observed during 2004 to 2006 against the scab pathogen at Jochira and Dharali (Gangotri fruit belt), which is endemic to apple scab. Data were collected from 6 to 12 year old cultivars. Scab evaluations were made in September of each year by collecting 30 vegetative terminals and 100 fruit on each tree. Selected shoots were equally spaced around the periphery of each tree. The incidence data were rated as tolerant, susceptible and highly susceptible based on the type of scab reaction produced on them, where 0 represents no macroscopic evidence of infection; 1, numerous or few minute pinpoint pits with no sporulation; 2, irregular or regular chlorotic or necrotic lesions varying from 2 to $5 \mathrm{~mm}$ with no sporulation; 3 , restricted necrotic lesions with sparse or abundant sporulation; and 4, extensive, abundantly sporulating lesions resulting in defoliation of severely affected leaves. Cultivars showing 0,1 and 2 infection types were rated as resistant and 3 and 4 as susceptible. Disease incidence was calculated by Croxall et al., (1952). 


\section{Results and Discussion}

The study area included seven districts of Garhwal division and six district of Kumaon division (Figure 1). Scab was wide spread appearing in all the areas surveyed and incidence varied from 0 to 100 percent in tree (Table 3). In Garhwal hills, the disease showed an increasing trend in all the apple areas. Most of the areas District Dehradun (26 $\%)$, Uttarkashi (41\% \%), Chamoli (21\%) and Tehri (4\%) had scab (Figure 2). In district Uttarkashi, the disease was found to be more prevalent and widespread. In all the villages surveyed, cent percent orchard was found infected, the highest percent infected trees being in Harsil, Dharali, Jhalla, Mukhuwa, Jochira, Cholmi Bagori, Purali, Jashpur and Shukhi (Table 3). In Puraola-Naugaon (Distt Uttarkashi), Chakrata (Distt Dehradun) and Gwaldam (Distt Chamoli) fruit belt, the incidence of scab was low and it was 1 to 13 percent on leaves and 0 to 6 percent on fruits. In Purola fruit belt, the disease was rather widespread than Chakrata fruit belt.

The highest percent infected orchards being in Harsil and Auli, Joshimath. The disease was most severe in leaves and fruits in both the place. The incidence of scab ranged between 05 to 65 per cent on foliage and 5 to 35 per cent on fruits and intensity ranged between 0.01 to 0.30 percent in leaves an on fruits was observed during 2004 to 2006 (Figure 3). Most of the orchards at Harsil recorded as high incidence as 85 per cent fruit scab. In Chakrata fruit belt, disease could not be seen in Chakrata, Rawna and Patti areas while in others 20 to 60 percent orchards were affected by scab. At one of the other hot spot, Tuni and Koti-Kanasar (Distt Dehradun) of Chakrata fruit belt, spring infection was less, however, secondary scab appeared in severe form during summer and the rainy season and continued until September first fortnight. In Kumaon hills, the scab incidence was negligible. Gangotri fruit belt can be considerd to be hot spot for apple scab disease in Uttarakhand hills (Figure 3).

Figure 4 show the average scab disease progression on selected apple cultivars during 2004-2006. Number of scab spots and area increased during period from $2^{\text {nd }}$ week of July to $1^{\text {st }}$ week of September (28 to 37 metrological week), however, diseased incidence increased on most of cultivars when the rate of secondary infection exceeded (Figure 5). The scabbed area on Delicious cultivars expanded rapidly in the second half of August without any corresponding increase in the area of scab. Progress of scabbed was most extensive on Royal, Red, Golden Delicious and intermediate on Rich-a-red, Starkrimson, Red chief, Red Gold. Red Delicious was the most susceptible cultivars in early August but the rate of epidemic progress decline thereafter. The scab incidence on Crab remained low throughout the assessment period (Table 4). The retardation of the epidemics on all cultivars in early August was probably due to cool and wet weather in May, June and July, reducing the level of infection. After July, intermittent rains and increasing temperature ranges leading to high humidity favored the spread of secondary infection as the conidia require high humidity for germination. However, Gupta and Lele (1980), Tomerlin and Jones (1983) and Verma and Sharma (2005) reported maximum disease severity in years of more than normal rainfall. The results of present finding are in agreement with above observation since there was more progress in lesion size, number and disease severity during summer progress more wetting period was received.

Relationship between the average diseased incidence on leaf and fruit of 12 cultivars with 28 weeks (metrological week 18 to 45 ) after initial appearance with disease incidence is shown in figure 6. 


\begin{tabular}{cl}
\hline Category & \multicolumn{1}{c}{ Rating } \\
\hline 0 & No visible lesion \\
1 & less than $10 \%$ fruit surface infected \\
2 & $10-25 \%$ fruit surface infected \\
3 & $25-50 \%$ fruits surface infected \\
4 & greater than $50 \%$ fruit surface infected \\
\hline
\end{tabular}

Table.1 A visual key for the assessment of apple scab on leaves (Croxall et al., 1952)

\begin{tabular}{ll}
\hline $\begin{array}{c}\text { Scab rating } \\
(\%)\end{array}$ & \multicolumn{1}{c}{ Type and extent of scab infection } \\
0.01 & Occasional units sow 1 or 2 infected leaves. \\
0.05 & Scab spots on 1 or 2 leaves in each unit \\
0.25 & Every units shows up to 5 small spots or their equivalent on \\
& about one-quarter of the leaves on each unit \\
& Every unit show 5 small spots or their equivalent on about $1 / 2$ of \\
& the leaves. \\
& Majority of leaves infected a few with about 25 percent of their \\
& area covered with spots. \\
& Almost every leaf infected with the scab area covering \\
5.00 & approximately 25 percent of the leaf surface on about one- \\
& quarter of the leaves. \\
& Every leaf infected, with the scab areas covering approximately \\
& All leaves infected, with the scab area covering almost the \\
& Every leaf infected with the scab areas covering 50 percent of \\
&
\end{tabular}

Observations to be made at 3 to 4 weeks of the petal fall if only single observation is to be taken.

Sampling unit means 5 runs of branches on each tree, chosen randomly round the tree to assess the percentage scab on the trees as a whole. 
Table.2 The visual assessment key development by Croxall et al., (1953) was used to cover the economically important range of scab.

Scab rating

Type and extent of scab on fruit

$(\%)$

0.01

0.10

0.50

1.00

5.00

10.00

25.00

50.00

75.00
Occasional units show one or two fruits infected

Small scab spots on one or two fruits in each unit.

Small scab spots on about one quarter of the fruits in each unit.

Up to 5 small scab spots on about $1 / 2$ of the fruits in each unit,

no cracking.

Scab spots on about $3 / 4$ of the fruits in each unit, occasional fruits may show cracking.

Every fruit in each unit shows scabbed area with few cracking.

Every fruit in each unit with large scab spots with up to $1 / 3$ of fruits cracked, fruits more variable in size and on the whole slightly smaller than fruit from the healthy ones.

Every fruit in each unit shows large scab spots with about $1 / 3$ of the fruits severely cracked and of non marketable grade. Fruit generally smaller than that from healthy trees.

Every fruit in each unit shows large scab spots with about $1 / 2$ of the fruits severely cracked and of non marketable grade. Fruit appreciably smaller than that from healthy trees.

Mean percentage of scabbed area per fruit be obtained by multiplying the number of fruits with the mean scab percentage of the group and the adding the product and dividing the figure by the total number of fruit examined. 
Table.3 Incidence of Apple scab in Garhwal and Kumaon Divisions of Uttarakhand Himalaya

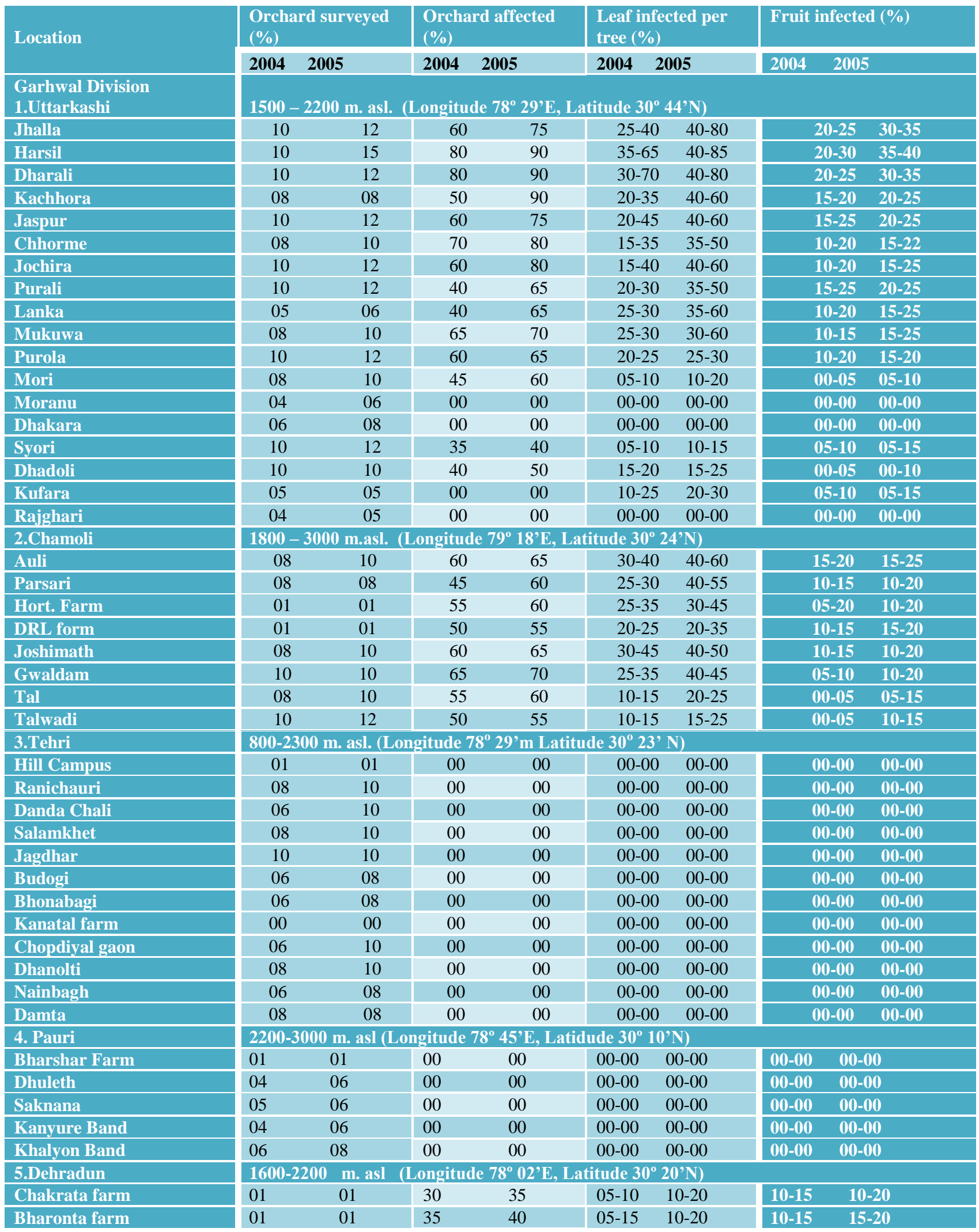


Int.J.Curr.Microbiol.App.Sci (2018) 7(10): 1166-1184

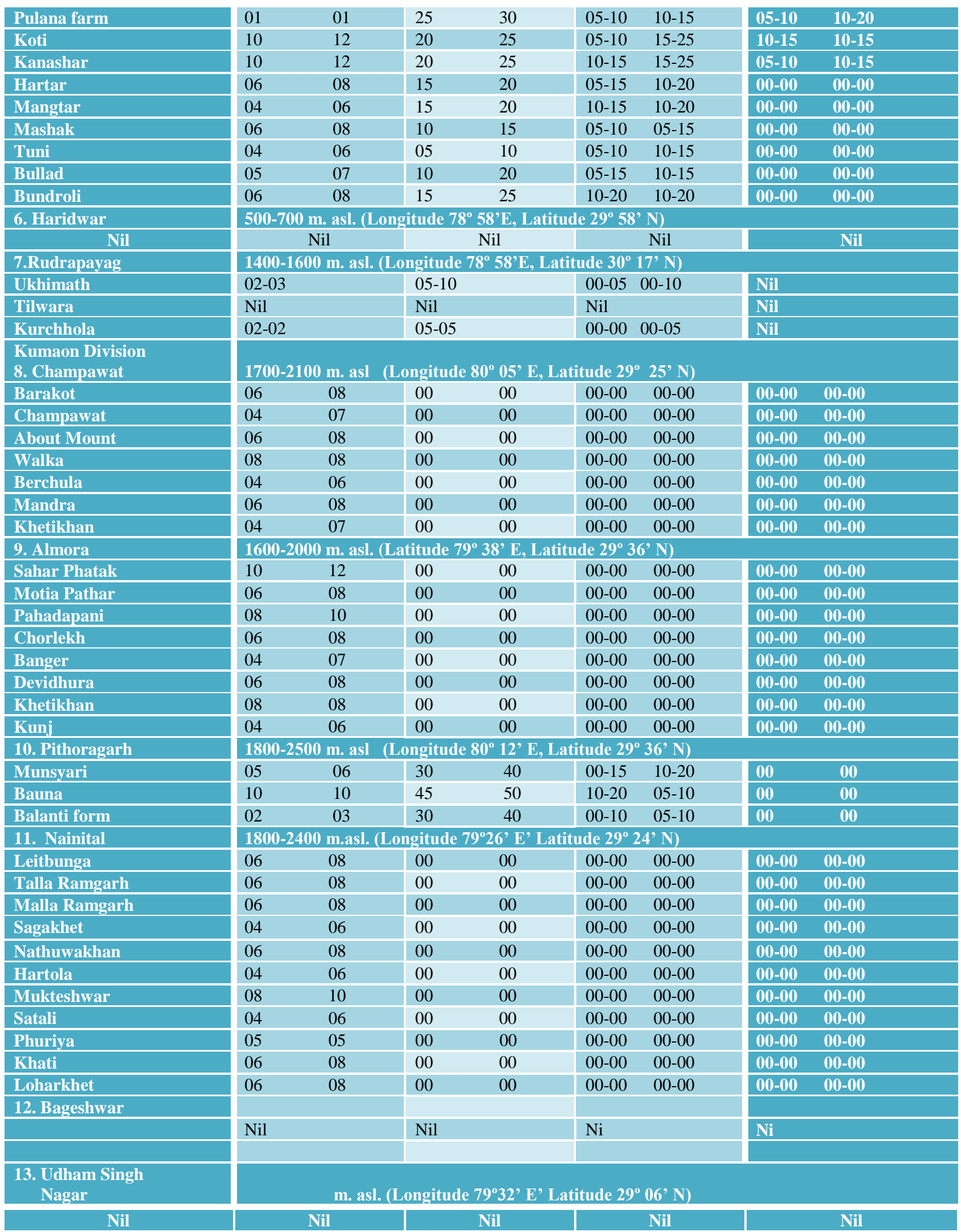




\section{Int.J.Curr.Microbiol.App.Sci (2018) 7(10): 1166-1184}

Table.4 Progress of scabbed in commercial cultivars of apple in Gangotri fruit belt

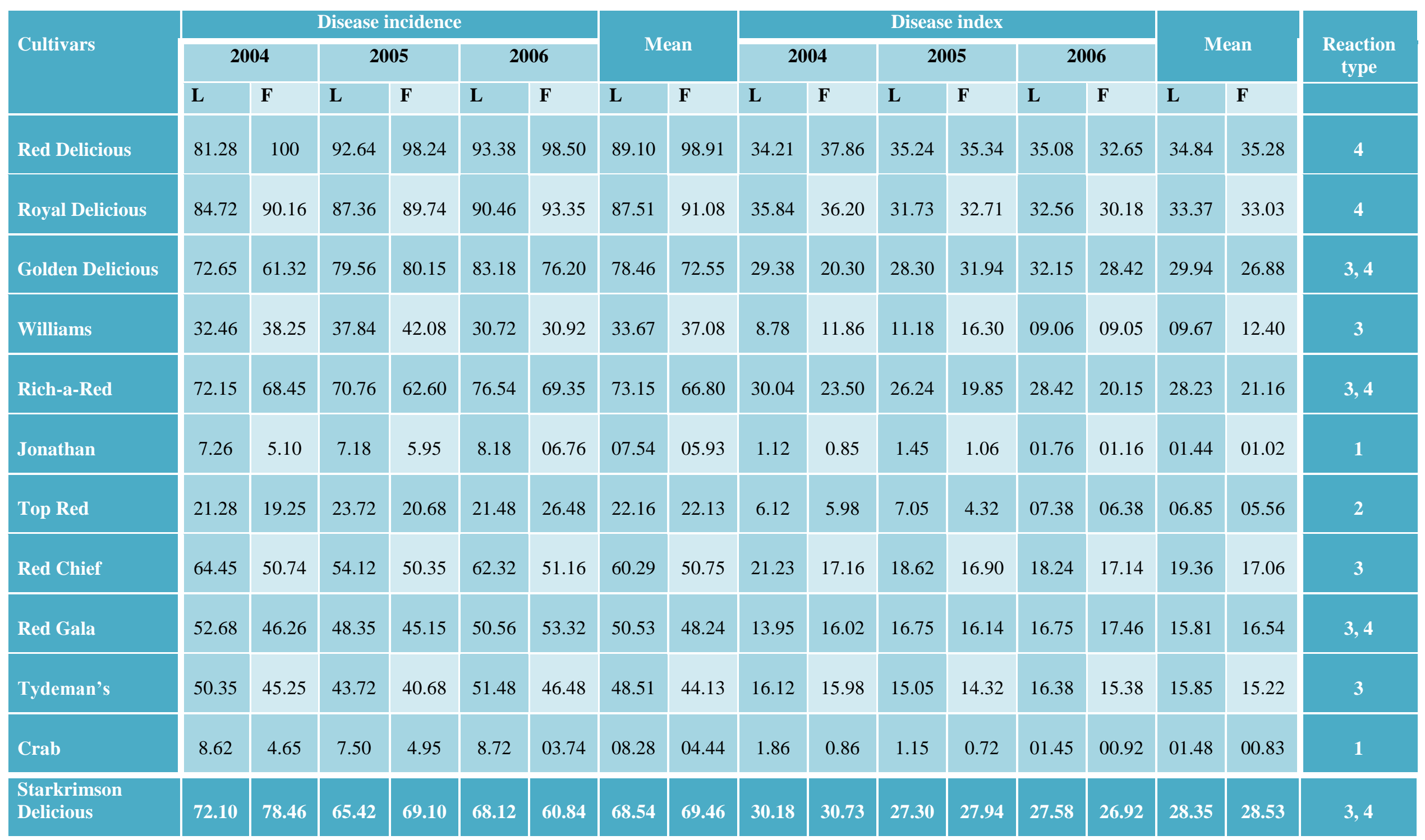


Fig.1 Geographical distribution and hot spots of apple scab in Uttaranchal hills

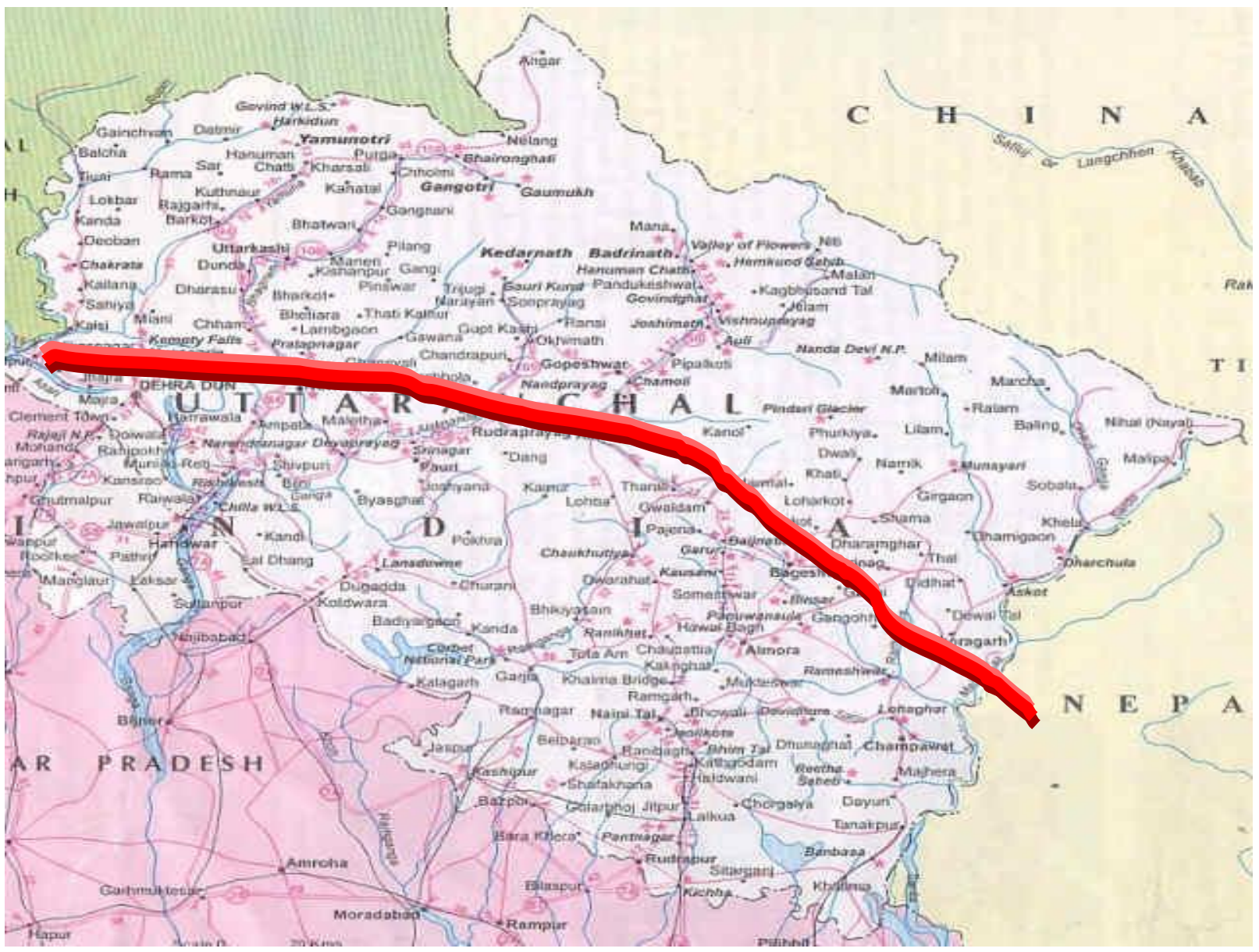

Fig.2 Estimated area (based on survey) under scab in apple orchards in six districts of Uttaranchal hills

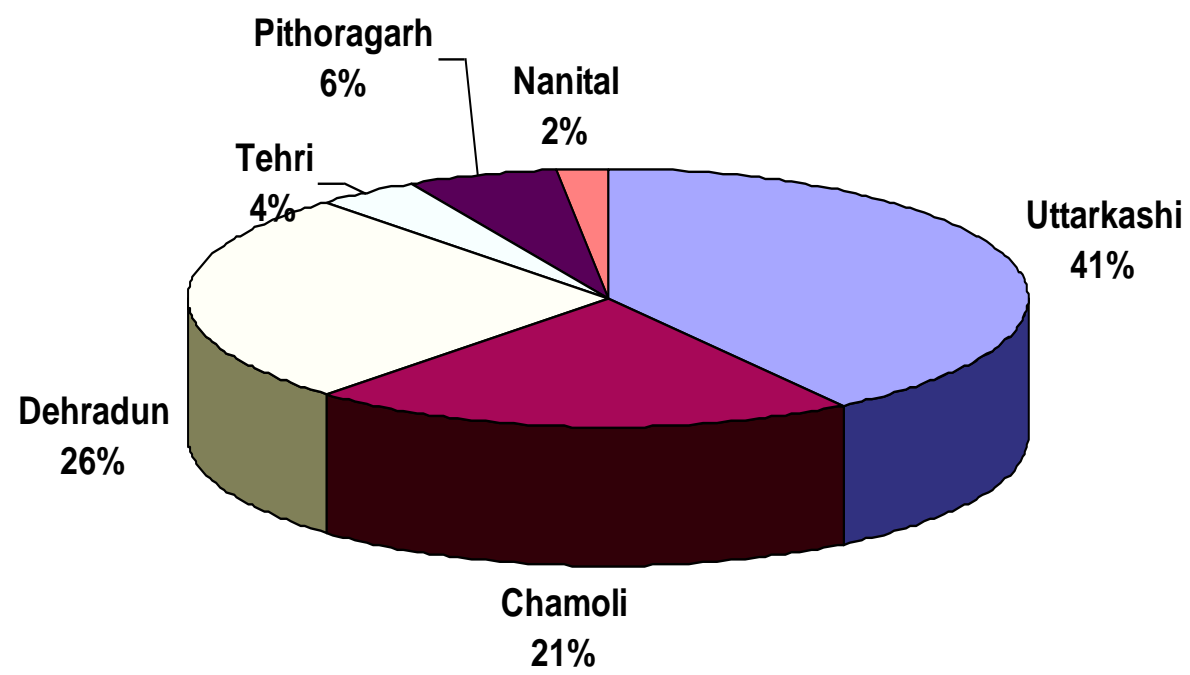


Fig.3 Field view of scab incidence in Gangotri fruit belt

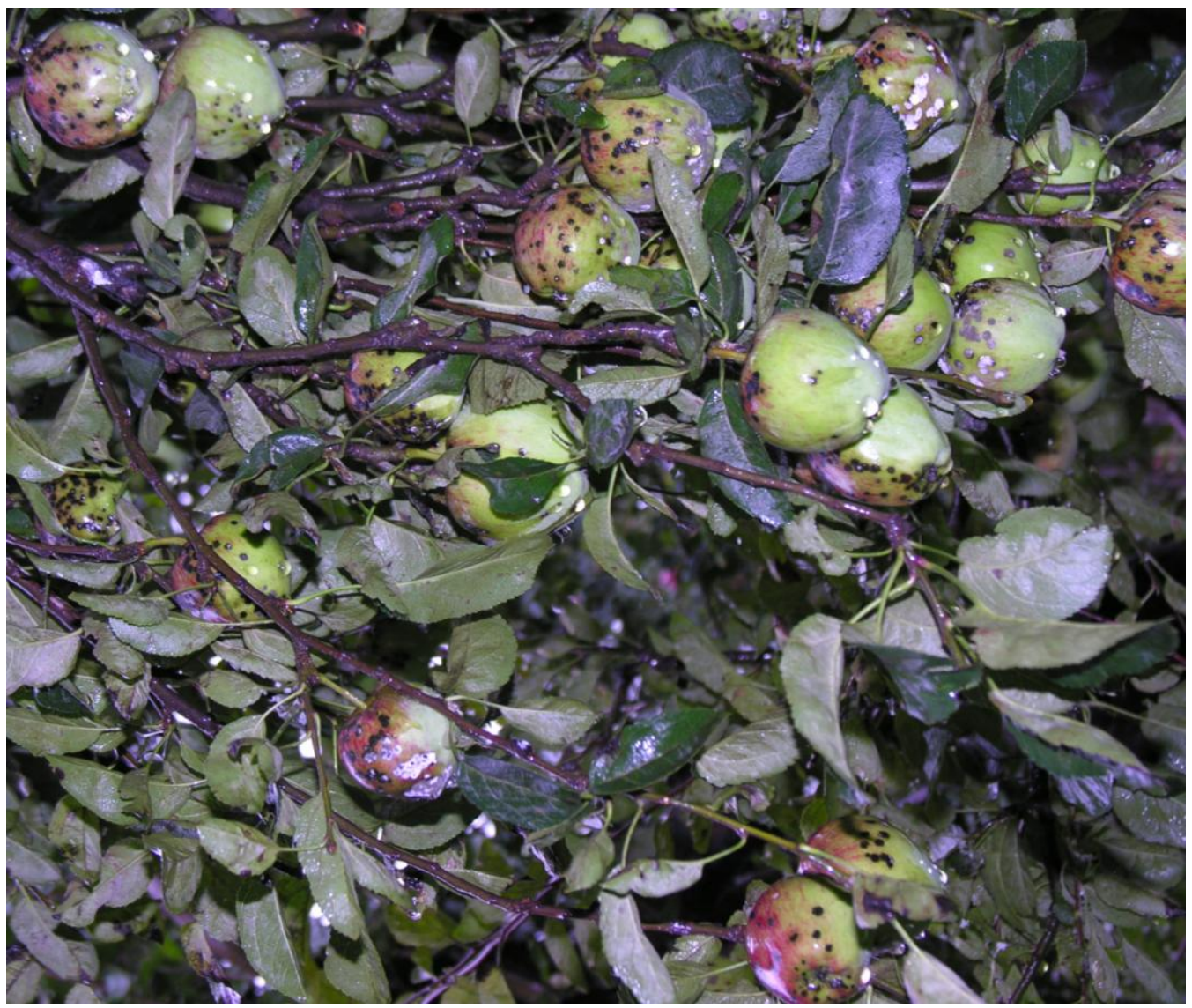

Fig.4 Scab disease progress on commercial cultivars during 2004 to 2006

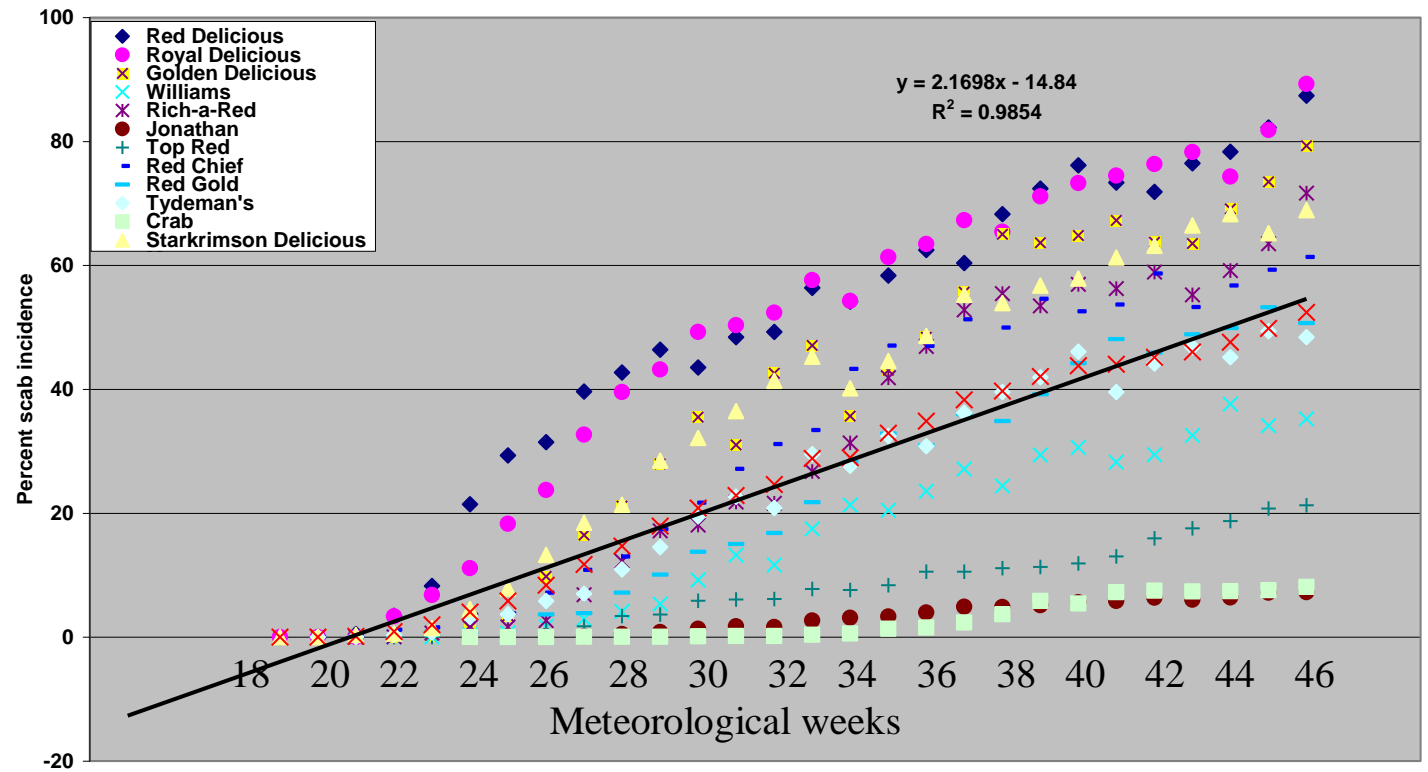


Fig.5 Relationship between index and incidence of apple scab
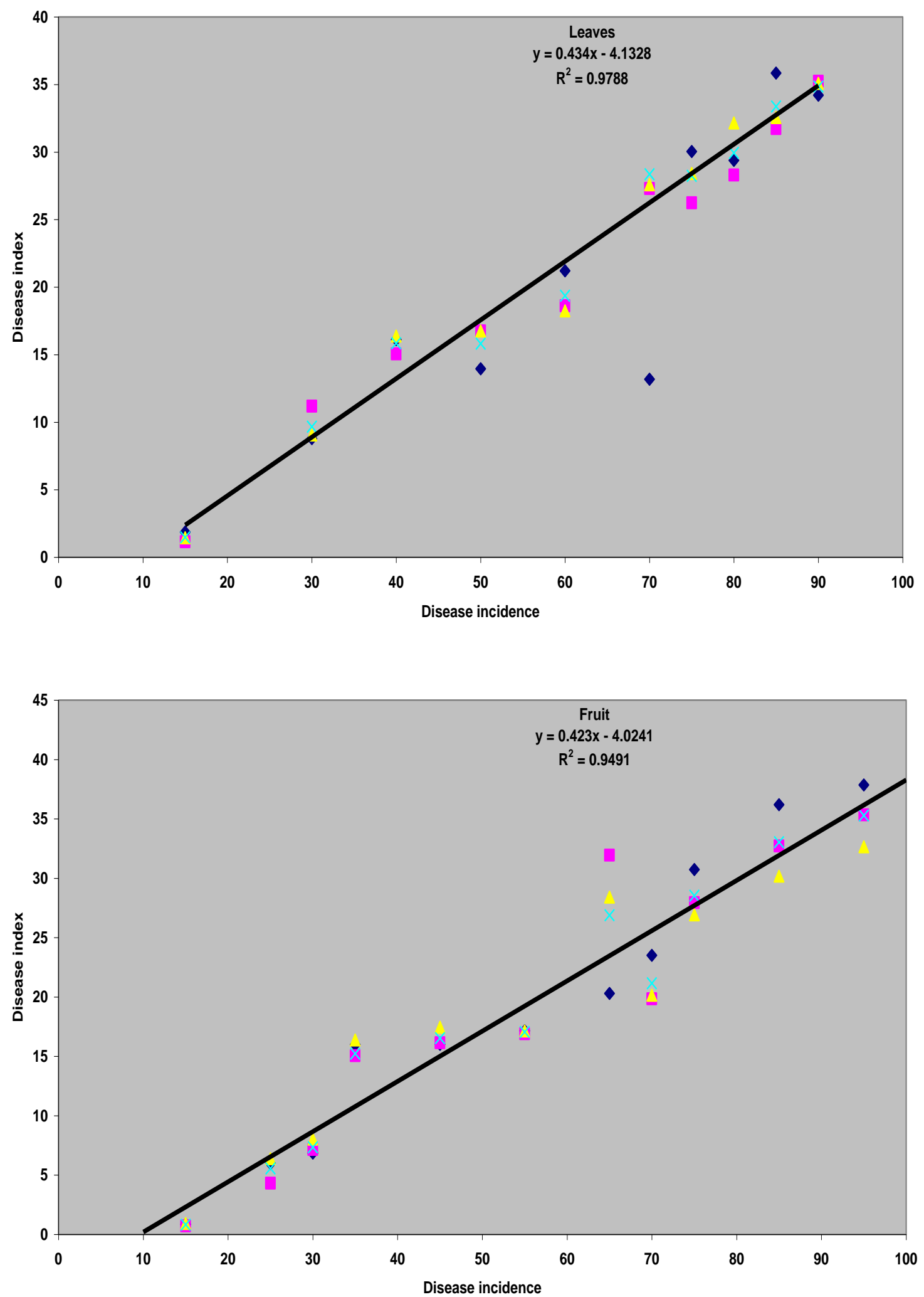
Fig.6 Weather data recorded through $\mu$ METOS of Gangotri fruit belt; Air Temperature $\left({ }^{\circ} \mathrm{C}\right)$; Relative Humidity (\%); Solar radiation $\left(\mathrm{W} / \mathrm{m}^{2}\right) ; \quad$ Bright Minutes $(\mathrm{m})$; $\quad$ Minutes with leaf wetness $(\mathrm{m}) ; \boldsymbol{\square}$ Wind speed $(\mathrm{m} / \mathrm{s}) ; \boldsymbol{~ P r e c i p i t a t i o n ~}(\mathrm{mm})^{\mathrm{s}}$
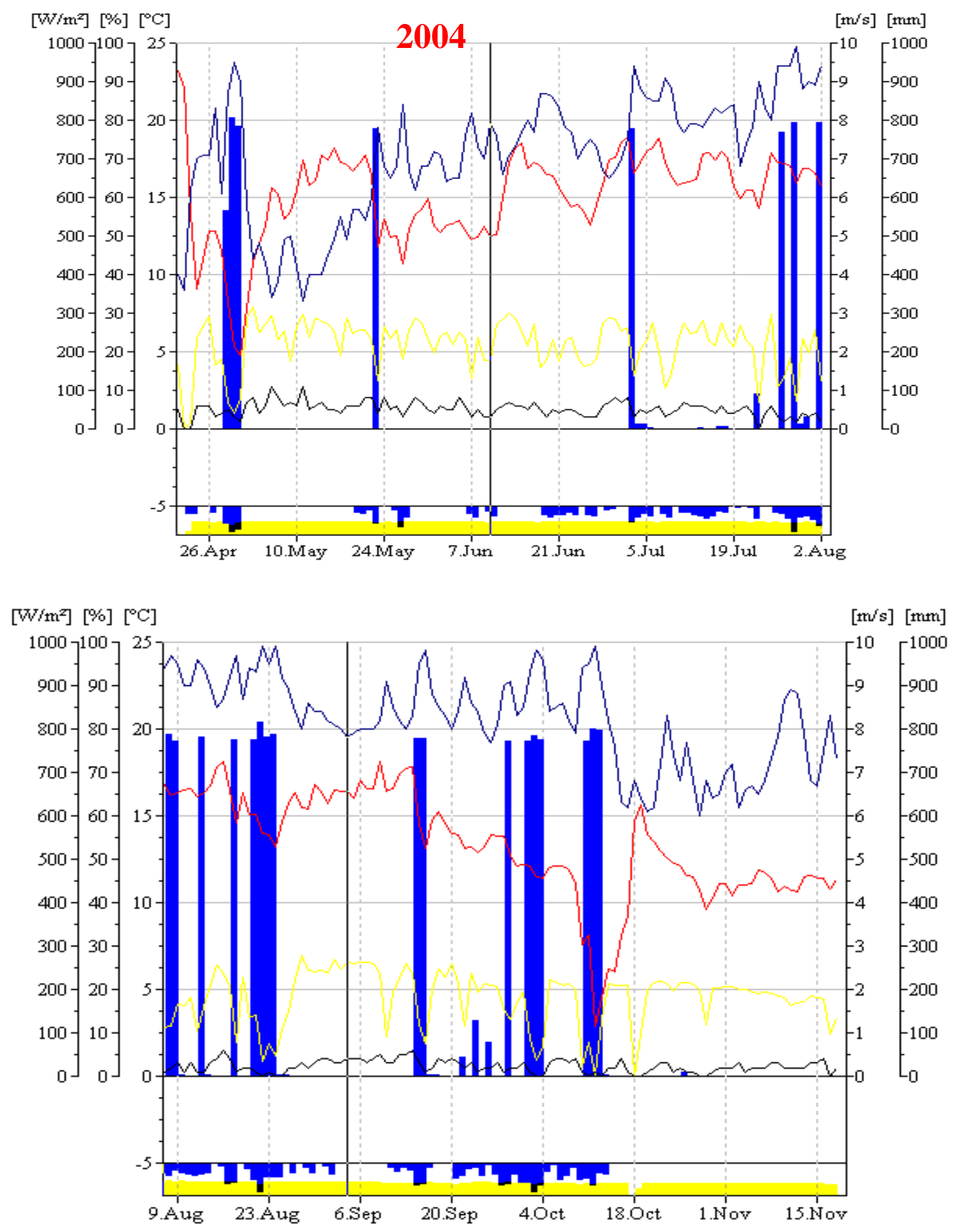

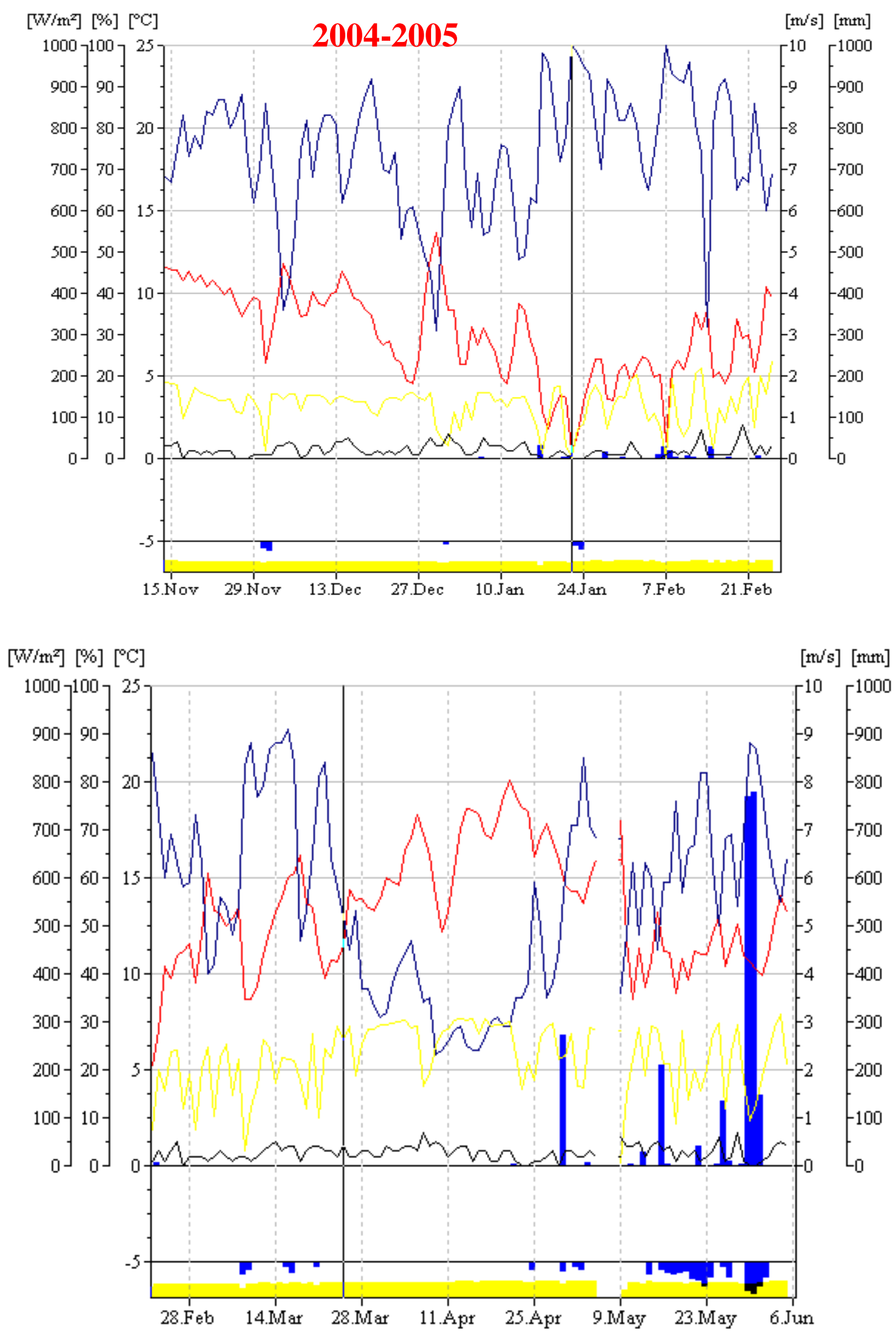

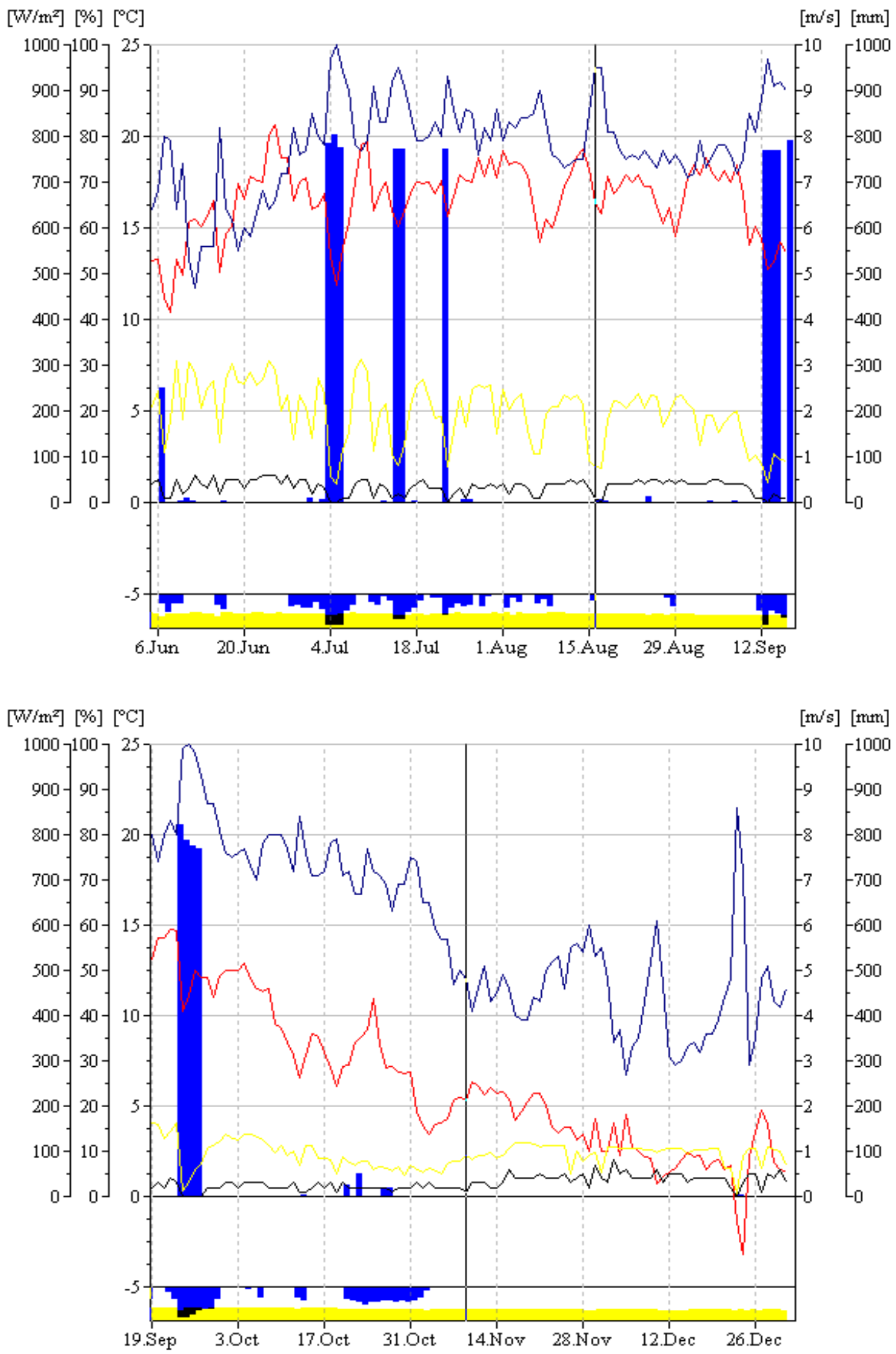

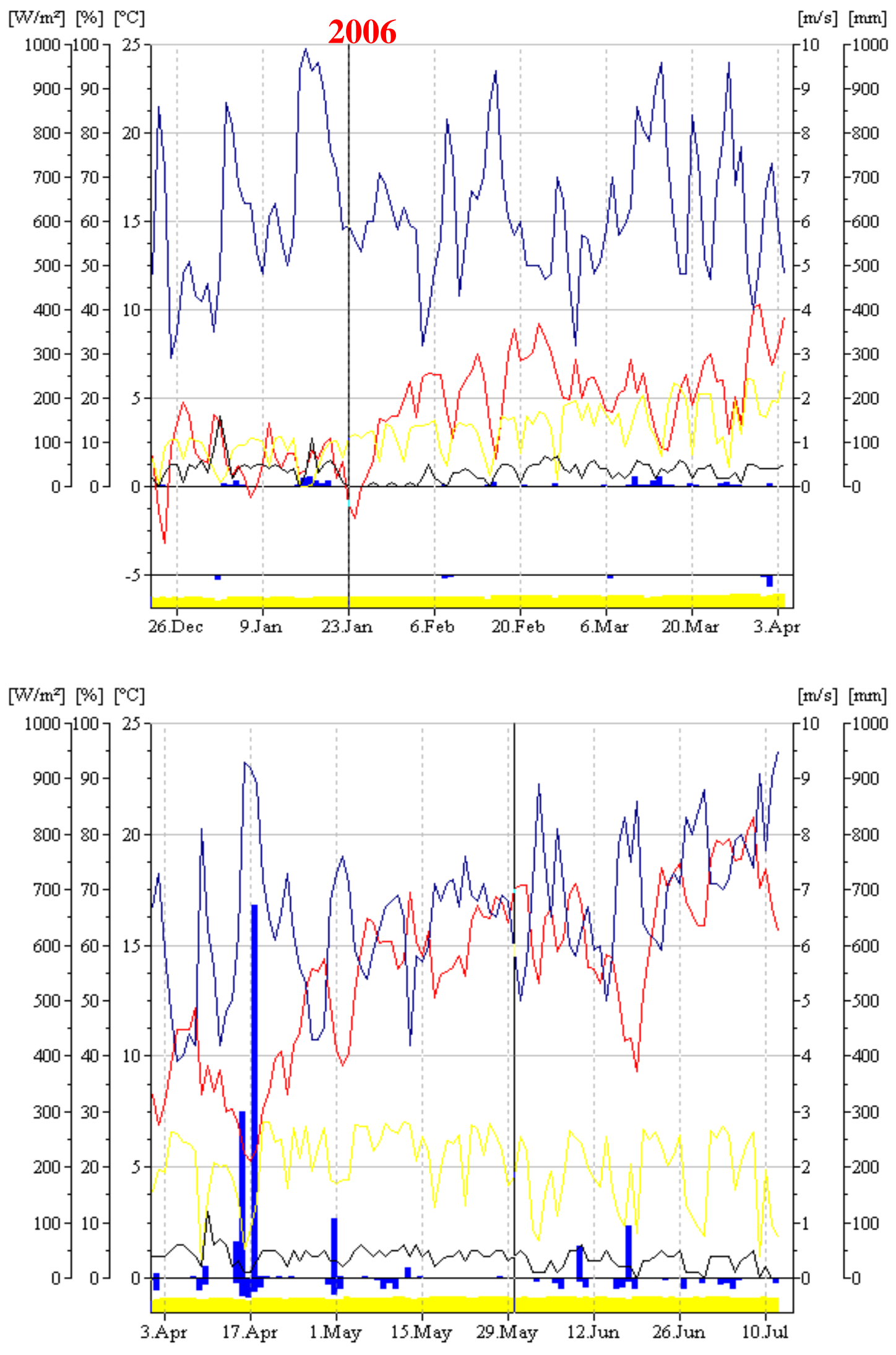

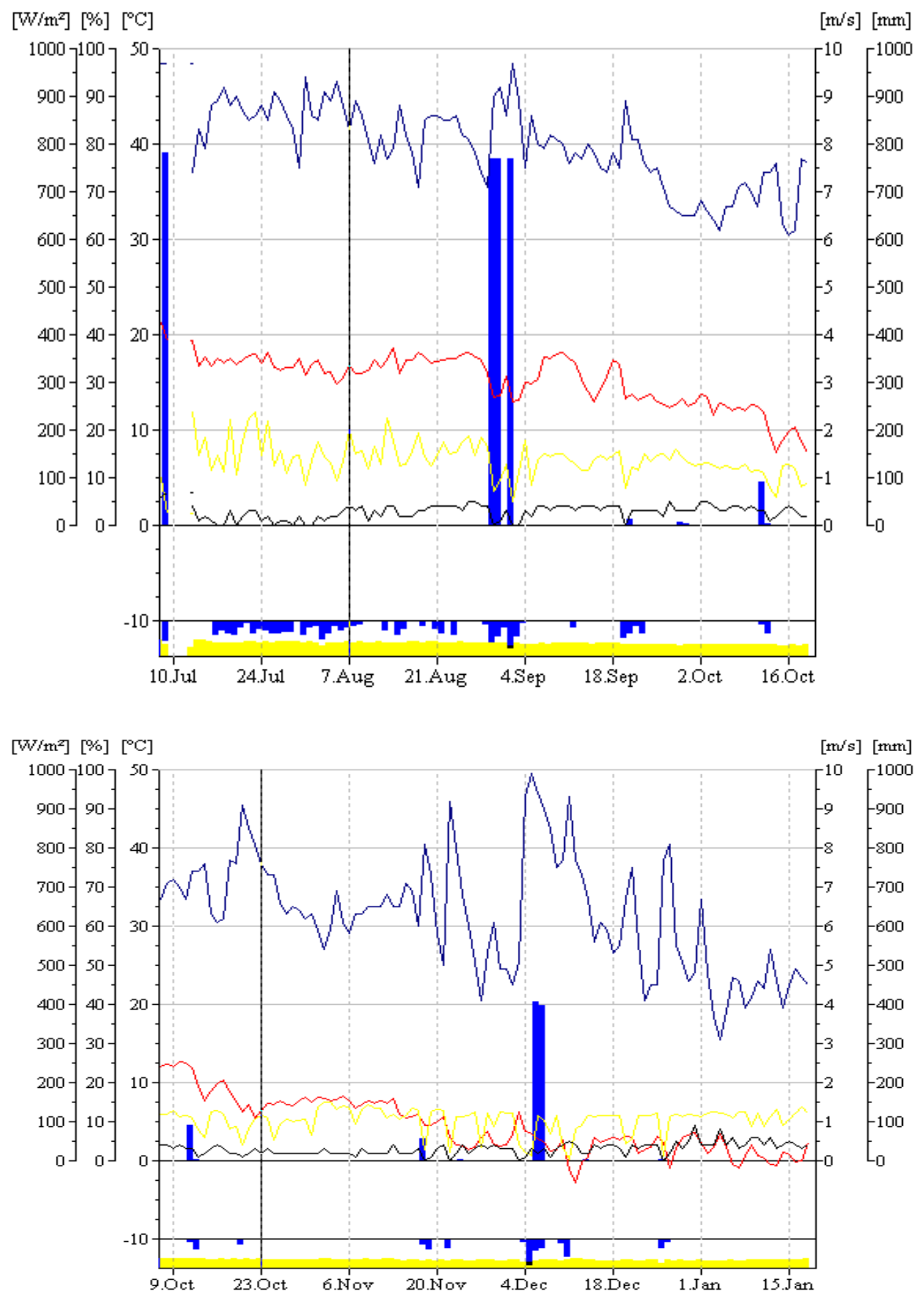

The regression line between metrological week and percent scab incidence of different cultivars gave best fit to the data based on $\mathrm{R}^{2}$ value (0.979). Considering all three years, the cultivars scab incidence and index relationship was linier and had greater variance as incidence increased (Figure 6). The equation of both leaves and fruits of cultivars $(\mathrm{Y}=-4.1328+0.434 \mathrm{x}, \mathrm{Y}=-4.0241$ $+0.423 \mathrm{x})$ showed the high relationship 
between disease index and incidence, and was highly correlated and could be predicated at high accuracy. The coefficient of determination $\left(\mathrm{R}^{2}\right)$ value for linear equation has been found to be 97.88 (leaves) and 94.91 percent (fruit) were highly significant (Figure 6). The relationships were highly positively correlated and would be predicted at on accuracy of more then 95 percent. The relationship between incidence and severity of foliar scab and fruit scab was consistent for each of six cultivers studied by Jeger (1981, 1983), and the relationship was explained by regression analysis. Seem (1984) reviewed correlation and regression method for identifying relationship between incidence and severity and provided different type of curves relationships. Gadoury and Mac Hardy (1986, 1996) indicate the relationship between incidence and severity was linear at incidence of foliar scab from 0.03 to 3 percent but was curvilinear over incidence to 25 percent. Under this study I tried to determine a general incidence and index relationship for apple scab and then to establish weather that relationship would remain the same for different years and cultivars. Holb (2000) and Holb et al., (2005) obtained similar epidemic progress of apple scab at different apple production systems in the Netherlands and Hungary.

By comparing the disease incidence and index of different cultivars for the year 2004 to 2005 , it is evident that the disease incidence was more during the year 2005 and 2006 as compared to 2004 in many cultivers. Out of all the cultivars, Red and Royal Delicious had maximum disease incidence $(89.10,87.51 \%$ (L), 98.91, $91.08 \%(\mathrm{~F})$ ) and index (34.84, $33.37 \%(\mathrm{~L}), 35.28,33.03 \%(\mathrm{~F}))$ and were highly susceptible. None of cultivars were found to be immune in the field. However, Jonathan and Crab were rated resistant during all the years (Table 4). Only one cultivars Top Red was moderately resistant to scab with scabbed area rating 2. Red Delicious, Royal Delicious, Golden Delicious, Williams, Richa-Red, Red Chief, Red Gold, Tyderman's, and Starkrimson

Delicious were found to be susceptible with scabbed area rating 3 and 4. Earlier Verma and Sharma (2005) and Sharma and Kaul (1994) reported Royal Delicious, Red Delicious, Golden Delicious, Red Gold, Richa-Red, McIntosh, Granny smith, Rush Pippin, Red June, Red spur, Winter Delicious, Black Ben and Davis are susceptible to scab in Himachal Pradesh. Thus, it can be said that the use of resistant varieties is an effective tool of management against scab. The cultivars found resistant or moderately resistant may be used in breading programs.

\section{References}

Croxall, H. E., Gwynee, D. C. and Jenkins, J. E. E. 1952 a. The rapid assessment of apple scab on leaves. Plant Pathol. 1: 39-41.

Croxall, H. E., Gwynee, D. C. and Jenkins, J. E. E. 1952 b. The rapid assessment of apple scab on fruit. Plant Pathol. 1: 8992.

Croxall, H. E., Gwynee, D. C. and Jenkins, J. E. E. 1953. The rapid assessment of apple on fruit. Plant Pathol. 2: 89-92.

Gadoury, D. M., and Mac Hardy, W. E. 1986. Forecasting ascospore dose of Venturia inaequalis in commercial apple orchards. Phytopathology 76: 112-118.

Gadoury, D. M., and Mac Hardy, W. E. 1996. Gupta, G. K., and Lele, V. C. 1980. Morphology, physiology and epidemiology of the apple scab fungus Venturia inaequalis (Cke.) Wint. In Kashmir valley. J.Agric. Sci. 50: 51-60.

Holb, I. J. 2000. Disease progress of apple scab caused by Venturia inaequalis in environmentally friendly growing 
system. International J. Hort. Sci., 6: 56-62.

Holb, I. J., Heijne, B., Withagen, J. C. M., Gall, G. M. and Jeger, M. J. 2005. Analysis of summer epidemics progress of apple scab at different apple production system in the Netherlands and Hungary, American Phytopathological Society 95: 10011020.

Jeger, M. J. 1981. Disease measurement in a study of apple scab epidemics. Ann. Appl. Biol. 99: 43-51.

Jeger, M. J. 1983. Damage and loss in fruit orchards caused by airborne fungal pathogens. In: Plant Disease: Infection damage and loss. R. K. S. Wood and G. J. Jellis, eds. Academic Press, London 225-235.

Kearns, H. G. H., Marsh, R. W. and Martin, H. 1945. Experimental spraying programme on apple and Long Ashton, 1945. Rep. Agric. Hort. Res. Stn. Bristol, 132-140 Pages.

MacHardy, W. E. 1996. Apple scab: Biology, Epidemiology and Management. American Phytopathological Society. APS Press, St. Paul, Minnesota, 545 Pages.

Moore, W. C. 1943. The measurement of plant disease in the field. Trans. Brit. Mycol. Soc. 26: 28-35.

Nutter, F. W., Jr., Teng, P. S., and Shokes, F. M. 1991. Disease assessment terms and concepts. Plant Dis. 75: 1187-1188.

Platter, T., and Kremer, F. W. 1962. Erfahrungen beider Ausbringung Von
Pflanzenschutzmitteln durch Beregnungsanlagen. Der Landwirt 16: 247-250.

Seem, R. C. 1984. Disease incidence and severity relationships Ann. Rev. Phytopathology. 22: 133-150.

Sharma, J. N. and Kaul, J. L. 1994. Emerging trends in temperate fruit production in India (Chadha, K. L., D. K. Uppal, R. N. Pal, R. P. Awasthi and S. A. Ananda, Eds.) NHB Technical Communication, National Horticulture Board, Gurgaoon, 62-67 pp.

Tehon, L. R., and Stout, G. L.1930. Epidemic diseases of fruit tree in Illinoise, 1922. III. Nat. Hist. Survey Bull. 18: 415-502.

Tomerlin, J. R., and Jones, A. L 1983. Development of apple scab on fruit in the orchard and during cold storage. Plant Dis. 67: 147-150.

Tomerlin, J. R., and Jones, A. L 1983. Effect of temperature and relative humidity on the latent period of Venturia inaequalis in apple leaves. Phytopathology 73: 5154.

Verma, K. D., and Sharma, J. N. 2005. Variability in Venturia inaequalis (Cke.) Wint. Causing scab disease of apple in Himachal Pradesh. J. Mycol. Pl. Pathol. 35: 27-29.

Zadoks, J. C. 1987. Rationale and concept of crop loss assessment for improving pest management and crop protection. In: Crop loss management and pest management. P. S. Teng. Ed. APS Press, St. Paul Minnesota. 270 Pages.

\section{How to cite this article:}

Prasad, R.K., K.P. Singh, R.K. Gupta and Kumar, J. 2018. Prevalence and Severity of Apple Scab in Uttarakhand Hills. Int.J.Curr.Microbiol.App.Sci. 7(10): 1166-1184.

doi: https://doi.org/10.20546/ijcmas.2018.710.130 